\title{
A Study on Factors Affecting Financial Performance of Indian Banking Sector
}

Ritu Bajaj ${ }^{1}$, Anshu $^{2}$

${ }^{1}$ BPSMV, Khanpur, Sonepat

${ }^{2}$ MRIM, Rohtak

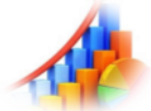

Email: drritu76@gmail.com

\section{JOURNAL OF BUSINESS MANAGEMENT \\ AND INFORMATION SYSTEMS \\ E-ISSN: 2394-3130}

Double Blind Peer Reviewed Journal

URL: http://jbmis.qtanalytics.in

\section{ABSTRACT}

In India there are different sectors which play the major role of accelerator in the growth of Indian economy. In this study, the area of focus is financial transactions sector specially banking sector which plays a momentous role in the economic growth by regulating and controlling the demand for and supply of money. The Indian banking sector supports the fastest growing economy of the world but it is grappling with multiple challenges. This research work analyzes the different variables that affect the financial performance of scheduled commercial banks in India and establish the relationship between selected macroeconomic variables and financial performance indicator. It also highlights the role of banking in changing economic scenario of India. The present study is empirical by nature. Descriptive cum exploratory research design has been used in this study. It has been found that GDP, CPI, exchange rate and lending interest rates are significant macroeconomic variables for determining the financial performance of scheduled commercial banks in India. It has been revealed that long term relationship exists between the selected macroeconomic variables and financial performance variables.

\section{KEY WORDS}

Indian Banking sector, macroeconomic variables, financial performance and scheduled commercial banks

\section{INTRODUCTION}

The interrelationship between macroeconomic variables and financial performance has been an issue of debate since the pioneering work by Tobin in 1960. Financial performance of banks has been the key issue amongst economists, policy makers and scholars at all level of the economies whether developed or developing. Due to globalization there is tremendous change worldwide in financial and banking services. Services sector is remarkably contributing in the productivity of any nation. The globalization effect on banking sector is still on verge in acquiring the required research consideration. Every day in the changing business environment banking sector is facing multiple financial issues and risk exposures.

\section{MACROECONOMIC CONCEPTS}

Macroeconomics includes the vast study which focuses on larger issues for an economy. Economists usually focus on the overall growth and performance parameters of an economy by analyzing certain macroeconomic variables. It has always been a popular area of interest 
among many economists to study about how an economy achieves output and consumption growth. It deals with cyclical trends of economically wide phenomena like rate of gross domestic production, price rise indexes, rates of interest, currency exchange price movements, money circulation, budget deficit and unemployment etc..

\section{FINANCIAL PERFORMANCE CONCEPTS}

Financial performance of any organization is considered as proper utilization of its financial resources for generating maximum revenue. To achieve this objective, it is generally relied upon comparison between individual financial variables with industry benchmarks and impact of various macroeconomic variables on such financial performance indicators.

Ganesan (1998), Nayak (2001), Bhatia and Verma (1998), Sarkar et al. (1998), Thamkirati (1996), Amandeep (1993), Karunagaran and Benjamin (1989), Vashist (1987) and Shirai (2002) worked prominently to review the well being of different banking systems from financial points of view. The main focus in these studies remained to analyze the profitability, liquidity, capital adequacy, risk and efficiency of commercial banks. These studies highlight the bank's concern for loan growth, deposit growth, efficiency ratios, capital ratios, return on assets, net interest margin, return on equity and credit quality as non-performing assets etc...

\section{TRENDS IN SELECTED AGGREGATES OF SCHEDULE COMMERCIAL BANKS IN INDIA.}

Table 1.1 indicates that the total number of aggregate deposits increased from 433818 crore in 1995 to 11426049 crore in 2018.
Indian banking system witnessed the demonetization during November, 2016 and growth rate in deposits and borrowings slackened in this phase. Deposits and borrowings of the banks increase by $32 \%$ during 2017. During demonetization a significant decline of 11.6 per cent has been observed in borrowing. Credit deposit ratio has been observed nearby $79 \%$ but it reached at its higher level of $90.3 \%$ during 2019.

Table: 1.1

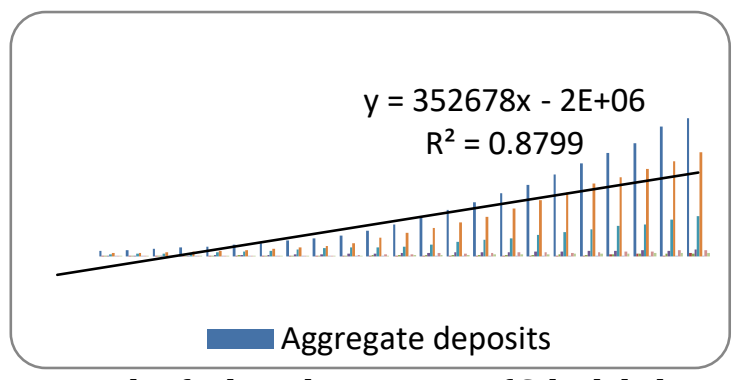

Trends of selected aggregates of Scheduled commercial banks in India

\section{Market Size of Indian Banking Industry}

As of 2019, there are 18 banks are working under the public sector undertaking, 22 banks working as private sector undertakings, 46 foreign banks, 56 regional rural banks, 1,562 urban cooperative banks and 94385 rural cooperative banks in India. All these banks are working under the central flagship authority of Reserve Bank of India. Besides these 10 small finance banks and 11 payment banks are also operating and running their operation to cope up with Indian Banking system. In India, these institutions play the role of intermediary authorities by creating and meeting ground for investors and savers through mobilization of financial resources.

Figure 1.1: Market share of banks in India

Bajaj, R. and Anshu (2020). A Study on Factors Affecting Financial Performance of Indian Banking Sector Journal of Business Management and Information Systems, 7(2), 9-16. https://doi.org/10.48001/ibmis.2020.0702002 


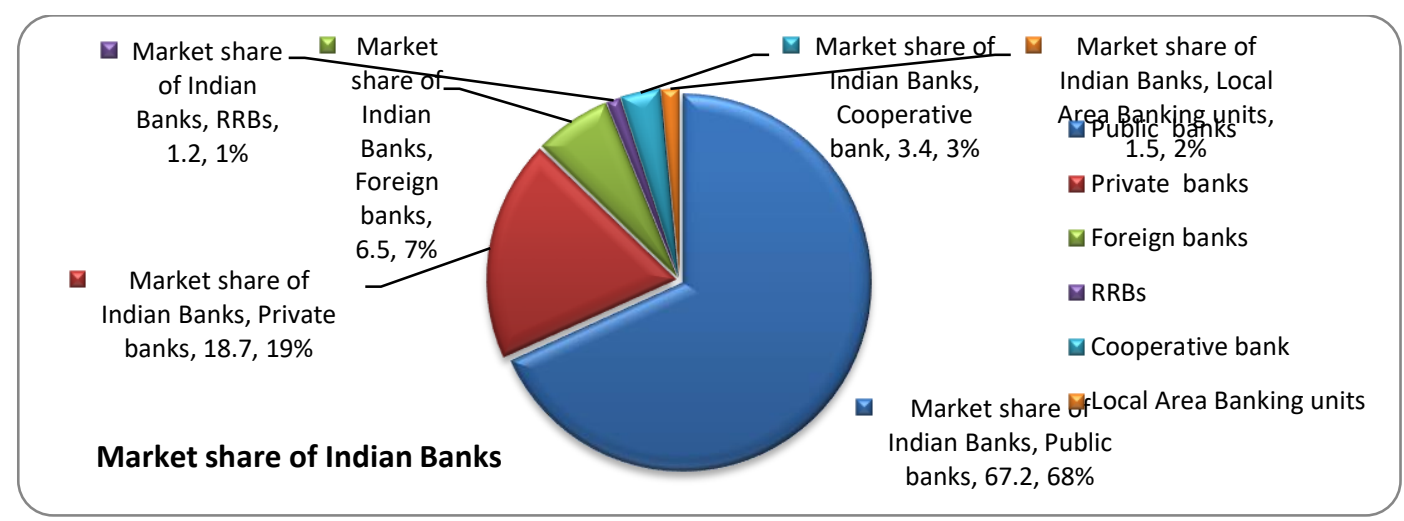

Source: RBI

\section{Figure: 1.2: Bank Group wise Return on} Advances

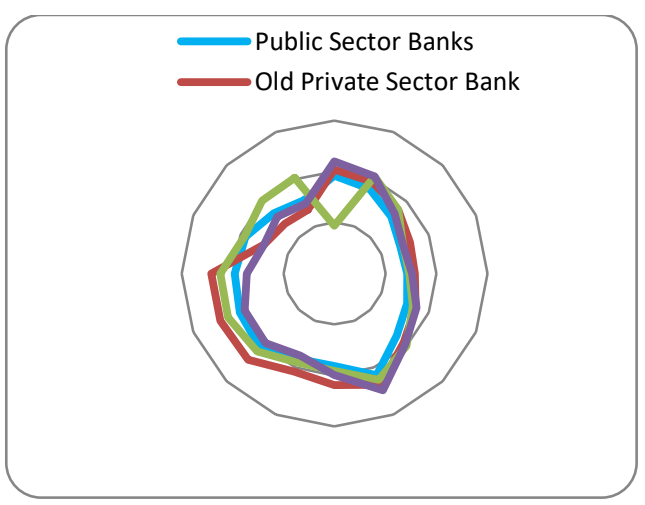

The figure1.2 presents that return on advances trends of new private sector banks achieved a continuous growth. Public sector banks performed well during2008-09 when return on advances reached to $10.31 \%$. As per statistical presentations of RBI, banking industry in India during 2008-09 return on advances for schedule commercial banks increased for all segments. During 2016-17 a slowdown in return on advances has been observed for public group, old private group and foreign group of banks.

\section{LITERATURE REVIEW}

Earlier research works on financial efficiency of banking industry were founded by eminent researchers as Short (1979), Bourke (1989),
Emery (1971) and Vernon (1971). These researchers were among the most primitive originator to associate macroeconomic and bank particular variables with financial soundness of banks. To recognize the various determinant factors of banks' performance and to establish the relationship among macroeconomic variables and performance variables several empirical studies were provided by researchers. Generally internal determinants or bank specific variables are associated with the management of banks and these are closely related to financial performance (Gungor, 2007). On the other hand external determinants are those determinants which reflect macroeconomic variables and remain out of control from the hand of any organization. Such variables are correlated to political, geographic, economical, demographic and regulatory environment that affect the overall financial soundness of banks.

Present literature presents various studies which include the inner determinants such as variables specific to banks, ratio analysis depicting the representing capital adequacy ratios, cost efficiency ratios, liquidity ratios, asset quality, and size. Economic growth, inflation rate, exchange rate, lending interest rates and real interest rates are the foremost external indicators that manipulate the performance of banks from financial point of view.

Bajaj, R. and Anshu (2020). A Study on Factors Affecting Financial Performance of Indian Banking Sector Journal of Business Management and Information Systems, 7(2), 9-16.

https://doi.org/10.48001/ibmis.2020.0702002 
There are several empirical studies that have studied the determinants of a particular country, while a lot of authors have focused over banks of a group of countries. Country specific researches have been performed to analyze the effects of macroeconomic indicators on specific financial competence variables in a particular banking system. These studies have been performed in United States (Angbazo, 1997; Berger, 1995), Malaysia (Sanusi and Ismail,2005 Staunton and Balashanmugam, 2002; Wasiuzzaman and Tarmizi, 2010; Guru et al.), Colombia (Barajas et al., 1999), Pakistan (Javaid, Anwar, Zaman and Gafoor, 2011; Ali et al.,2011), Dietrich(2009), Wanzenried (2009). Afanasiff et al., (2003) studied about the banking industry in Brazil while Mamatzakis and Remoundos(2003), Kosmidou (2006) focused over banking sector of Greece., Tunisian banking industry has been analyzed by Naceur (2003) and Bennaceur and Goaied (2008) while in India Badola and Verma (2006), Sharma \& Mani (2012), Sharma \& Singh (2016) remained among the prominent researcher to investigate the macroeconomic and economic aspects of banking segments. The related studies have been found in Taiwan (Ramlall, 2009), Japan ( Chong, Wilson \& Lui, 2010), and Korea (Sufian \& Habibhulla, 2011) and China (Heffernan and Fu, 2008).

The concerned literature has been presented below to put emphasis on the work done on this subject matter in India and abroad. It emphasizes and delineates the various issues as well as various methodologies adopted for the analysis. There are many studies related with the present area have been presented below to investigate the relationship among macroeconomic indicators and the financial indicators of Indian banks. The aim of the study is to find out the different factors affecting financial performance of Indian banking sector.

\section{RESEARCH METHODOLOGY}

- Research Design: The present study is descriptive cum diagnostic.

\section{- Sampling and Target Population:} Schedule commercial banks as per $2^{\text {nd }}$ schedule of RBI have been selected for the sample of the study. Schedule commercial banks

- Period of Study: The period from 1990-91 to 2017-18 has been selected for this study. The 27 years period selected for the present study is fairly long, cyclically well balances and gives homogeneous and reliable data.

\section{- Tools and Techniques}

The prescribed objectives of the study have been achieved through the use of E-views- 9 Descriptive statistics through backward stepwise regression techniques.

\section{ANALYSIS OF THE STUDY}

To find out different factors affecting financial performance of Indian banking sector

As the banking sector plays a fascinating role in the advancement of Indian economy. The financial performance of this industry depends on various pillars. To obtain the different variables affecting financial competence of the Indian banking sector, we make a model using the bank distinctive variables and macroeconomic variables. As per the literature we observed that financial performance in the different countries was affecting through different variables. In most of the studies it has been observed that the explanatory variables of financial performance for the different banking sectors were analyzed at micro point of view and also at the macro level. Thus the following equation presents an attempt to explain the financial soundness with in perspective of scheduled commercial banks of Indian banking sector.

Bajaj, R. and Anshu (2020). A Study on Factors Affecting Financial Performance of Indian Banking Sector Journal of Business Management and Information Systems, 7(2), 9-16. https://doi.org/10.48001/ibmis.2020.0702002 


$$
\delta_{j t}=C+\sum_{n=1}^{n} \beta_{n} X_{i t}^{n}+E_{i t}
$$

Where $\delta_{j t}$ is the financial efficiency of scheduled commercial bank $\mathrm{j}$ on $\mathrm{t}$ time and $\mathrm{j}=$ $1, \ldots . . \mathrm{N} ; \mathrm{t}=1, \ldots . \mathrm{T}$. In this equation stability is denoted by $\mathrm{C}$. The term in the equation $\beta_{n} X^{n}{ }_{i t}$ denotes the coefficient value of $n$ explanatory variables that affects the financial efficiency of the banking region in India. $E_{i t}$ is the error term or we can say the disturbance due to explanatory variables.

The factors affecting financial performance of banks with the scheduled commercial category in India can be further divided as per the above equation.

$$
\delta_{j t}=C+\sum_{k=1}^{K} \beta_{k} X^{k}{ }_{i t}+\sum_{m=1}^{M} \beta_{m} X^{m}{ }_{i t}+E_{i t}
$$

Where $X^{n}{ }_{i t}$ with the denoted superscripts $\mathrm{k}$ and $m$ present the internal or bank particular variables and macroeconomic or external variables affecting the financial performance of the scheduled commercial banks in India.

Table: 1.1

\begin{tabular}{|l|l|}
\hline \multicolumn{2}{|l|}{ Dependent Variables: } \\
\hline Return on Assets (ROA) & $\begin{array}{l}\text { Net proceeds / Overall } \\
\text { Assets }\end{array}$ \\
\hline Return on Equity (ROE) & $\begin{array}{l}\text { Net proceeds / Sum total } \\
\text { of Equity }\end{array}$ \\
\hline $\begin{array}{l}\text { Capital to Risk Weighted } \\
\text { Assets (CRAR) }\end{array}$ & $\begin{array}{l}\text { Tier1+Tier2 Capital / } \\
\text { Weighted Assets of risk } \\
\text { category }\end{array}$ \\
\hline $\begin{array}{l}\text { Nonperforming assets } \\
\text { (NPA) }\end{array}$ & Net NPAs/Total Loans \\
\hline Net Interest Margin(NIM) & $\begin{array}{l}\text { Net Interest } \\
\text { income/Total assets }\end{array}$ \\
\hline
\end{tabular}

Table: 1.2

\begin{tabular}{|l|l|}
\hline $\begin{array}{l}\text { The Bank-Particular internal/ Explanatory } \\
\text { Variables }\end{array}$ \\
\hline Deposits (DEPO) & Total Deposits/Assets \\
\hline Liquid assets (LIQ) & \multicolumn{1}{|c|}{ Liquid asset/ Overall assets } \\
\hline Bank Size (BS) & $\begin{array}{l}\text { Logarithm value of total } \\
\text { possessions in terms of assets } \\
\text { with banks }\end{array}$ \\
\hline
\end{tabular}

\begin{tabular}{|l|l|}
$\begin{array}{l}\text { Expenditure } \\
\text { composition (EFC) }\end{array}$ & $\begin{array}{l}\text { Expenses incurred on Fee and } \\
\text { Commission/Total Assets }\end{array}$ \\
\hline $\begin{array}{l}\text { Income } \\
\text { Composition (IFC) }\end{array}$ & $\begin{array}{l}\text { Income earned from Fees and } \\
\text { Commissions/Total Assets }\end{array}$ \\
\hline
\end{tabular}

Table: 1.3

\begin{tabular}{|l|l|l|}
\hline \multicolumn{3}{|c|}{ The Macroeconomic Explanatory Variables } \\
\hline GDPR & $\begin{array}{l}\text { Economic } \\
\text { Activity }\end{array}$ & $\begin{array}{l}\text { Real Gross Domestic } \\
\text { Product Rate }\end{array}$ \\
\hline EXR & Exchange rate & Indian Rupees to US\$ \\
\hline CPI & $\begin{array}{l}\text { Annual Rate of } \\
\text { price rise }\end{array}$ & $\begin{array}{l}\text { Consumer Price } \\
\text { Index for inflation }\end{array}$ \\
\hline LINR & $\begin{array}{l}\text { Interest Rate } \\
\text { for lending }\end{array}$ & Prime Lending Rate \\
\hline UEMP & $\begin{array}{l}\text { Unemployment } \\
\text { Rate }\end{array}$ & $\begin{array}{l}\text { Indian } \\
\text { Unemployment rate }\end{array}$ \\
\hline MS & Money Supply & $\begin{array}{l}\text { M3 Money Supply in } \\
\text { Indian Economy }\end{array}$ \\
\hline
\end{tabular}

Table 1.4: Stepwise Regression results for factors affecting Return on Assets (ROA)

\section{Dependent Variable: ROA \\ Method: Stepwise Regression}

Total regressors: 11

\begin{tabular}{|l|l|l|l|l|}
\hline Variable & $\begin{array}{l}\text { Co- } \\
\text { efficient }\end{array}$ & $\begin{array}{l}\text { Std- } \\
\text { Error }\end{array}$ & $\begin{array}{l}\text { t- } \\
\text { statistics }\end{array}$ & Prob* \\
\hline C & 6.9553 & 2.1163 & 4.7039 & $0.0001^{*}$ \\
\hline GDPR & 3.1026 & 1.0331 & 3.0032 & $0.0065^{*}$ \\
\hline CPI & -0.0288 & 0.0077 & -3.7329 & $0.0012^{*}$ \\
\hline EXR & -3.1194 & 1.0431 & 2.9902 & $0.0067^{*}$ \\
\hline LINR & -0.1681 & 1.0331 & -3.0032 & $0.0003^{*}$ \\
\hline MS & 0.0578 & 0.0143 & 4.04237 & $0.0006^{*}$ \\
\hline BS & 0.0395 & 0.0147 & 2.6921 & $0.0136^{*}$ \\
\hline DEPO & 2.8632 & 1.1835 & 2.1025 & $0.0005^{*}$ \\
\hline
\end{tabular}

Where R-squared $=0.879467$, Adjusted R-square $=$ 0.826960 , S.E of regression $=0.621111$, F-statistics $=$ 14.84480, Prob.(F-Statistics) $=0.000003$, Mean Dependent Var. $=0.621111$ Durbin - Watson stat $=$ 2.00136.

The result presents the variables selection results for return on assets. From the backwards stepwise regression results it has been found that GDPR, CPI, EXR, LINR, MS, BS and DEPO are the most suitable variable for determining the return on assets. GDPR, CPI, exchange rate, lending interest rate, money supply, size of bank in terms of log value of total

Bajaj, R. and Anshu (2020). A Study on Factors Affecting Financial Performance of Indian Banking Sector Journal of Business Management and Information Systems, 7(2), 9-16.

https://doi.org/10.48001/ibmis.2020.0702002 
assets, and deposits to total assets have been found significant at $5 \%$ level of significance.

\section{Table 1.5: Stepwise Regression results for factors affecting Return on Equity}

Dependent Variable: ROE

Method: Stepwise Regression

Total tegressors:11

\begin{tabular}{|l|l|l|l|l|}
\hline Variable & $\begin{array}{l}\text { Co- } \\
\text { efficient }\end{array}$ & $\begin{array}{l}\text { Standard- } \\
\text { Error }\end{array}$ & $\begin{array}{l}\text { t- } \\
\text { statistics }\end{array}$ & $\begin{array}{l}\text { Prob. } \\
\text { value* }\end{array}$ \\
\hline C & -9.9660 & 6.9494 & -8.1779 & $0.002^{*}$ \\
\hline GDPR & -0.2111 & 0.1815 & -1.1629 & 0.258 \\
\hline CPI & -0.3428 & 0.2765 & -6.2396 & $0.029^{*}$ \\
\hline EXR & 2.4329 & 0.4297 & 5.6616 & $0.000^{*}$ \\
\hline LINR & 26.7906 & 1.7680 & 15.152 & $0.000^{*}$ \\
\hline MS & 0.389541 & 0.461204 & 0.8446 & 0.408 \\
\hline LIQ & -0.3311 & 0.2145 & -5.6356 & $0.000^{*}$ \\
\hline IFC & 3.426189 & 0.7812 & 4.1256 & $0.001^{*}$ \\
\hline DEPO & 2.7412 & 0.6213 & 5.45672 & $0.000^{*}$ \\
\hline
\end{tabular}

Where R-squared $=0.959574$, Adjusted R-square $=$ 0.847446 , S.E of regression= 2.618514, F-statistics= 79.12168, Prob.( F-Statistics) $=0.000000$, Mean Dependent Var.= 8.36481, Durbin - Watson stat= 1.99036, S.D. dependent Var $=1.652165$,Akaije info criterion $=4.981505$, Schwarz criterion $=5.317463$

Stepwise Regression results for factors affecting Capital adequacy ratio (CRAR) for Scheduled commercial banks in India.

Table: 1.6 presents the variables selection results for return on assets. From the backwards stepwise regression results it has been found that GDPR, EXR, LINR, CPI, DEPO, BSIZE, LIQ and EFC are the most suitable variable for determining the capital to risk weighted assets

\section{Table: 1.6: Stepwise Regression results for factors affecting CRAR}

Dependent Variable: CRAR

\begin{tabular}{|l|l|l|l|l|}
\hline Variable & $\begin{array}{l}\text { Co- } \\
\text { efficient }\end{array}$ & $\begin{array}{l}\text { Std- } \\
\text { Error }\end{array}$ & $\begin{array}{l}\text { t- } \\
\text { statistics }\end{array}$ & Prob* \\
\hline C & -8.2982 & 11.173 & -6.4264 & 0.0663 \\
\hline GDPR & -0.6138 & 0.5284 & -1.1616 & 0.2590 \\
\hline EXR & -0.2352 & 0.0720 & -3.2628 & $0.0039^{*}$ \\
\hline LINR & -0.9213 & 0.4238 & -2.1737 & $0.0419^{*}$ \\
\hline
\end{tabular}

\begin{tabular}{|l|l|l|l|l|}
\hline CPI & 0.1335 & 0.0500 & 2.3375 & $0.0148^{*}$ \\
\hline DEPO & 0.8959 & 0.5024 & 2.7832 & $0.0424^{*}$ \\
\hline BSIZE & 3.9944 & 1.5309 & 2.6090 & $0.0183^{*}$ \\
\hline LIQ & -0.5366 & 0.4156 & -1.2910 & 0.2140 \\
\hline EFC & -0.3372 & 0.1608 & -3.0968 & $0.0413^{*}$ \\
\hline
\end{tabular}

Where R-square value $=0.810387$, Adjusted $R^{2}=$ 0.710004 , S.Error of regression $=0.889712$, F-stat. $=$ 8.072924, Probability ( F-Stat.) $=0.000131$, Mean Dependent Var. $=12.15222$, Durbin - Watson stat= 2.0122, S.D. dependent Var $=1.652165$,Akaike information measurement $=2.882280$, Schwarz information results $=3.362220$

End user price inflation index, currency trade rate, lending rate, assets size, and composition of fee \& commission expenditure have been found significant at $5 \%$ level of significance. Beside these variables other bank precise and macroeconomic variables are rejected from the model as per above results. Jointly these variables produce $81 \%$ deviation in the dependent variable CRAR.

\section{Table 1.7: Stepwise Regression results for factors affecting NPA}

Dependent Variable: NPANA

Method: Stepwise Regression

Total Regressors:11

\begin{tabular}{|l|l|l|l|l|}
\hline Variable & $\begin{array}{l}\text { Co- } \\
\text { efficient }\end{array}$ & $\begin{array}{l}\text { Standard- } \\
\text { Error }\end{array}$ & $\begin{array}{l}\text { t- } \\
\text { statistics }\end{array}$ & Prob* \\
\hline C & -25.382 & 9.2018 & -6.1272 & $0.0000^{*}$ \\
\hline GDPR & -22.238 & 2.5348 & -8.8898 & $0.0000^{*}$ \\
\hline EXR & 0.1574 & 0.0400 & 3.9272 & $0.0011^{*}$ \\
\hline LINR & 0.9548 & 0.0368 & 2.5923 & $0.0190^{*}$ \\
\hline CPI & 0.1839 & 0.0366 & 5.0162 & $0.0001^{*}$ \\
\hline MS & 0.0912 & 0.3658 & 3.1458 & $0.0020^{*}$ \\
\hline UEMP & 22.534 & 2.5348 & -8.889 & $0.0000^{*}$ \\
\hline BSIZE & 1.3187 & 0.4945 & 2.6665 & $0.0163^{*}$ \\
\hline LIQ & 0.4176 & 0.5934 & 2.5556 & $0.0015^{*}$ \\
\hline
\end{tabular}

Where R-squared $=0.951105$, Adjusted R-square $=$ 0.891101 , S.E of regression $=0.500996$, F-statistics $=$ 88.07700, Prob.( F-Statistics $)=0.000000$, Mean Dependent Var. $=11.7210$, Durbin - Watson stat= 1.998561, S.D. dependent Var $=2.947098$, Akaike info criterion $=1.733679$, Schwarz criterion= 2.213618

Bajaj, R. and Anshu (2020). A Study on Factors Affecting Financial Performance of Indian Banking Sector Journal of Business Management and Information Systems, 7(2), 9-16.

https://doi.org/10.48001/jbmis.2020.0702002 
Table1.7: presents the variables selection results for nonperforming assets for scheduled commercial banks. From the backwards stepwise regression results it has been found that GDPR, CPI, EXR, LINR, MS, LIQ, UEMP and BSIZE are the most suitable variable for determining the non performing assets. Annual rates for gross domestic production, price rise index for consumer goods, exchange rate, lending interest rate, supply of money, unemployment rate, liquid assets to entire assets and bank size in term of log value of assets have been found significant at $5 \%$ level of significance.

\section{Table 1.8: Stepwise Regression results for factors affecting Net interest margin}

Dependent Variable: NIM

Method: Stepwise Regression

Total Regressors: 11

\begin{tabular}{|l|l|l|l|l|}
\hline Variable & $\begin{array}{l}\text { Co- } \\
\text { efficient }\end{array}$ & Std-Error & $\begin{array}{l}\text { t- } \\
\text { statistics }\end{array}$ & Prob* \\
\hline C & 12.556 & 2.6149 & 4.8016 & $0.0001^{*}$ \\
\hline GDPR & 0.1802 & 0.0506 & 3.2054 & $0.0049^{*}$ \\
\hline CPI & -0.1401 & 0.1703 & -2.8155 & $0.0054^{*}$ \\
\hline EXR & -0.3903 & 0.0075 & -5.2380 & $0.0001^{*}$ \\
\hline LINR & 1.2126 & 0.2250 & 4.4989 & $0.0003^{*}$ \\
\hline MS & -0.0142 & 0.0184 & -0.7211 & 0.4254 \\
\hline LIQ & 0.0708 & 0.0495 & 1.4306 & $0.0464^{*}$ \\
\hline IFC & 0.0708 & 0.0465 & 1.4306 & 0.1697 \\
\hline DEPO & 0.556245 & 1.521678 & 3.715511 & $0.0002^{*}$ \\
\hline
\end{tabular}

Where R-squared $=0.796018$, Adjusted R-square $=$ 0.703138 , S.E of regression $=0.214287$, F-statistics= 15.291048, Prob. (F-Statistics) $=0.004912$, Mean Dependent Var. $=2.874074$, Durbin - Watson stat= 2.02344, S.D. dependent Var $=1.304002$, Akaike info criterion $=2.018196$, Schwarz criterion $=2.450142$

Table: 1.8 presents the variables selection results for net interest margin. From the backwards stepwise regression results it has been found that GDPR, CPI, EXR, LINR, MS, LIQ, IFC and DEPO are the most suitable variable for determining the return on net interest margin. GDPR, price rise index, exchange rate, lending interest rate, supply of money, unemployment rate, liquid assets to entire value of assets and bank size in term of log value of assets have been found significant at 5 percent level of significance

\section{FINDINGS OF THE STUDY}

As per the studies mentioned in the review we observe that in most of the country's, financial presentation of the banks can be considered through return ratio for assets, return as proportion to total equity, non performing loans, capital to risk weighted assets and margin through net interest. As per the CAMEL approach these variable are also suitable to measure the financial effectiveness of banking divisions. Now the present study analyzes the financial performance of scheduled commercial banks in India. With the help of backward stepwise regression techniques most suitable financial performance variables has been identified further.

1. GDPR, CPI, EXR, LINR, MS, BS and DEPO are the most suitable variable for determining the return on assets. GDPR, CPI, exchange rate, lending interest rate, money supply, size of bank in terms of log value of total assets, and deposits to total assets have been found significant.

2. GDP, CPI, EXR, LINR, MS, LIQ, IFC, DEPO have been found significant variables for determining the return on assets ratio of scheduled commercial banks.

3. GDPR, EXR, LINR, CPI, DEPO, BSIZE, LIQ and EFC are the most suitable variable for determining the capital to risk weighted assets.

4. GDPR, CPI, EXR, LINR, MS, LIQ, UEMP and BSIZE are the most suitable variable for determining the non performing assets.

5. GDPR, CPI, EXR, LINR, MS, LIQ, IFC and DEPO are the most suitable variable for determining the return on net interest margin

Bajaj, R. and Anshu (2020). A Study on Factors Affecting Financial Performance of Indian Banking Sector Journal of Business Management and Information Systems, 7(2), 9-16. 


\section{REFERENCES:}

1. Abruime,T.(2008). Determinants of bank profitability: Macroeconomic evidence from Nigeria. Retrieved from http://papers.ssrn.com/sol3/papers.cfm?abstract_i $\mathrm{d}=1231064$

2. Acaravci, S. K. \& Calim, A. E. (2013). Turkish banking sector's profitability factors. International Journal of Economics and Financial Issues, 3(1), 27-41.

3. Adidu, F.A. and Olanye, P.A. (2006). Basic Small Business Entrepreneurship: A Modern Approach, Royal Pace Publisher. Baggs, J., Beaulieu, E., and Fung, L. (2009). Firm survival, performance, and the exchange rate. Can. J. Econ. Can. Déconomique 42, 393-421.

4. Bain, J.S. (1951). The Relation of Profit Rate to Industry Concentration: America Manufacturing, 1936-1940. Quarterly Journal of Economics 65(3).

5. Demirgüç-Kunt, A., \&Detragiache, E. (1998). The Determinants of Banking Crises: Evidence from Developed and Developing Countries. International Monetary Fund, 45(1),81-109.

6. Demirhan, D. (2010), Turkiye'deki Mevduat Bankalarinin Finansal Yapiya Iliskin Kararlarinin.

7. Demsetz, H. (1973), Industry Structure. Market Rivaly and Public Policy Journal of Law and Economics 18(3).

8. India Brand Equity Foundation (IBEF) (2014), "Banking Sector in India", July, 2014, www.ibef.org.

9. Issah, M. \& Antwi, S.,(2017). Role of macroeconomic variables on firms' performance: Evidence from the UK. Cogent Economics \& Finance (2017), 5: 1405581

10. Jensen, M.C. (1986). Agency costs of free cash flow, corporate finance, and takeovers. Am. Econ. Rev. 76, 323-329. 